The Center for Global Energy, International Arbitration, and Environmental Law

The University of Texas-School of Law

Research Paper No. 01-10

Electricity Transmission In the U.S. -

Legal Issues and Trends

Ryan Thomas Trahan 


\section{ELECTRICITY TRANSMISSION IN THE U.S. - Legal Issues and Trends}

Spring 2010

By Ryan Thomas Trahan ${ }^{1}$

Center for Global Energy, International Arbitration, and Environmental Law, University of Texas at Austin School of Law

\section{TABLE OF CONTENTS}

INTRODUCTION \& ORGANIZATION

I. PlanNING AND MANAGEMENT OF THE GRID ............................ 1

II. PlanNing AND Siting THE TRANSMISSION FACILITIES ........... 13

III. INTRODUCTION TO THE SMART GRID ...................................... 24

${ }^{1}$ The author is a former Research Fellow at the Center. He is currently an Associate at Paul, Hastings, Janofsky \& Walker and can be contacted at ryantrahan@paulhastings.com. 


\section{Introduction \& Organization}

The U.S. electricity transmission infrastructure is undergoing historic change; a short, upfront look at current and projected investment activity provides a sense of the scale and impact. Under the auspice of the American Reinvestment and Recovery Act, the Department of Energy is authorized to award nearly \$38 billion in grants_-and make or guarantee \$127 billion in loans-over the next few years to modernize the United States's energy infrastructure and pursue a more independent national energy policy. ${ }^{2}$ Roughly $14 \%$ of the authorized grant money, or $\$ 4.5$ billion, is specifically directed towards Electricity Delivery and Energy Reliability, a category focused on upgrading the U.S. electricity transmission grid. ${ }^{3}$ In practice, many of those grants are to be matched, dollar for dollar, by private investment. ${ }^{4}$ Similar priorities are reflected in the regular budget process as illustrated by the 2011 fiscal budget which features a 6.8 percent increase for the Department of Energy’s budget, to $\$ 28.4$ billion, and a 5 percent increase for the Office of Energy Efficiency and Renewable Energy, to $\$ 2.36$ billion. $^{5}$

Apart from federal departmental budgets and stimulus grant spending, regional investment in transmission upgrades continues unabated and, in terms of aggregate investment, may outstrip the federal stimulus grant awards. In Texas alone, a $\$ 4.93$ billion transmission line build-out gained approval in early 2009 and is set to begin construction later this year. ${ }^{6}$ That project was followed by an announcement at the end of December 2009 that the regional operator for the Texas grid is considering another slate of projects over the next five years that would be worth over $\$ 8.2$ billion. $^{7}$

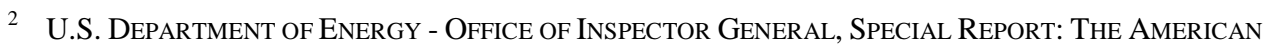

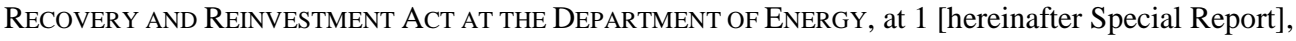
available at http://www.ig.energy.gov/documents/OAS-RA-09-01-New508-G.pdf. The Department of Energy's final rules on the loan guarantee guidelines were released in early December of 2009. See U.S.

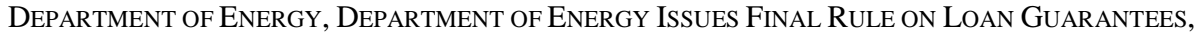
http://www.energy.gov/news2009/8369.htm [Last Visited Jan. 14, 2009].

3 See Special Report, supra note 1.

4 See U.S. Department of Energy, Recovery Act Selections For SMart Grid Investment Awards - By CATEGORY, available at http://www.energy.gov/recovery/smartgrid_maps/SGIGSelections_Category.pdf.

5 Office of Management ANd Budget, Budget of THE U.S. GOVERNMENT - FisCAL YeAr 2011 at 69, 70, available at http://www.whitehouse.gov/omb/budget/fy2011/assets/budget.pdf.

6 See Press Release - Public Utility Commission of Texas, Texas Public Utility Commission Approves Wind Transmission Plan (July 17, 2008) [hereinafter PUCT July Press Release], available at http://See www.puc.state.tx.us/nrelease/2008/071708.pdf.

7 See Electric Reliability Council of Texas, Report on Existing And Potential Electric System CONSTRAINTS AND NEEDS - DECEMBER 2009, at 7, available at http://www.ercot.com/news/presentations/2009/2009_Constraints_and_Needs_Report_21DEC2009.pdf (proposals include plans to build over 5,729 miles of transmission lines). 
Recent reports from the world of venture capital investment also signal continued strength in the broad area of "clean tech." Clean tech is an area which drives demand for transmission and distribution infrastructure by funding innovative projects from plug-in cars to electricity monitoring software to renewable electricity generation. The final numbers from 2009 show that nearly $25 \%$ of all venture capital dollars went into clean tech investments for a total of over \$5.6 billion, with deal volume at 557 transactions. $^{8}$

As much as the magnitude of this public and private investment is noteworthy, the physical impacts of the actual construction of the transmission facilities may be even more so. For example, the $\$ 4.93$ billion Texas transmission project (mentioned above) will add an estimated 2,200 miles of transmission lines and facilities in the state of Texas alone. ${ }^{9}$ At least one study forecasts that over 56,000 acres of wildlife habitat will be affected by the resulting construction. ${ }^{10}$ Considering that there are similar planned and ongoing projects throughout the nation, it is not hyperbole to state that the national transmission infrastructure build-out will change the visual appearance of the country.

Why is there such an intense contemporary focus on the seemingly staid area of electricity transmission infrastructure? In short, the construction build-out is largely predicated on a national will to develop centralized renewable energy generation. Centralized energy generation refers to the huge wind and solar power plants which—unlike distributed energy devices such as rooftop solar panels—require transmission links to populated areas. ${ }^{11}$ Commentators offer myriad reasons to justify this desire, ranging from providing for national security and environmental protection to creating sustainable economic development. Whatever the reasons, it is an inescapable reality that the continued deployment of centralized renewable energy resources, such as utility-scale wind and solar power plants, is currently dependent on the development of, and integration with, a more

8 Press Release, Cleantech Group LLC and Deloitte LLP, Clean Technology Venture Investment Totaled \$5.6 Billion in 2009 Despite Non-Binding Climate Change Accord in Copenhagen, Finds the Cleantech Group and Deloitte (Jan. 6, 2010), http://www.prnewswire.com/news-releases/clean-technology-ventureinvestment-totaled-56-billion-in-2009-despite-non-binding-climate-change-accord-in-copenhagen-finds-thecleantech-group-and-deloitte-80796417.html.

9 See PUCT July Press Release, supra note 4; Public Utility Commission of Texas, Docket 35665 (March 2009).

10 Estimate based on 200 foot right-of-ways. See Lorie Woodward Cantu, Texas High Wires - A Balancing Act for Private Landowners, Texas Wildlife at 26 (July, 2009), available at http://texaswildlife.org/files/Texas\%20High\%20Wires\%20article,\%20electronic\%20copy,\%206-12-09.pdf.

11 An alternate policy supported by some commentators is to create more distributed power generation through the use of rooftop solar panels, geothermal pumps, efficiency improvements, and single-home sized wind turbines. Because these devices create power at the site of their ultimate consumption, the wide-ranging transmission infrastructure currently being contemplated would arguably not be necessary. Proponents of centralized energy, however, question whether these distributed devices are cost-effective and capable of meeting the aggressive national renewable energy generation goals. Others argue that both approaches are necessary to address the looming problem of climate change and the goal of energy independence. 
robust U.S. electricity transmission infrastructure. ${ }^{12}$ Insofar as that dependency persists—and the United States's energy strategy remains focused on centralized generation-both the energy policy goals of the U.S. and, to some extent, the larger international goals of combating global climate change, are bound to the continued development of the U.S. electricity transmission network.

This paper is meant to provide a timely introduction and an edited currency review of developments in this pivotal area of electricity transmission development. With the considerable range and technical depth of transmission-related activity, however, only selective coverage is provided so as to maintain a palatable introduction. The first two sections of this paper both feature the topic of planning (although it is often treated separately in other writings) to highlight why planning issues cannot be easily divorced from the business of managing a more integrated grid, or the siting of its transmission facilities. Section I tackles the planning and managing of the grid and provides background on the structure and controversies affecting its development. Section II examines planning and physical siting of the transmission lines and substations, i.e., a review of the developments related to questions of where to place the physical facilities, and on whose land. Rather than being a simple technical exercise, planning and siting decisions are interwoven with strong conflicts between competing federal and state authorities, as well as individual landowners. Each of these sections is augmented with a relevant case example from the state of Texas, followed by a review of select recent issues from other areas of the country that illustrate larger themes. The paper ends with a brief third section providing an initiation to the Smart Grid, a separate, incomplete, solution to the current energy challenges.

The choice of Texas for the case example perhaps requires a brief upfront explanation. In addition to simple partisanship, Texas was chosen because it is unique in regard to electricity transmission issues. Due to quirks in the history of transmission development in the U.S., Texas is the site of a nearly self-contained transmission grid, and it has been at the forefront of operative electricity deregulation. Moreover, it is the state with the most wind energy generation nationwide and, as a result, confronted certain problems with limits in transmission capacity earlier than many other states. Because of these and other attributes to be later discussed, Texas provides a mostly selfcontained case example and a workable comparative context for developments that are happening nationwide.

12 Generally speaking, there are two reasons centralized renewable energy generation is linked to a more robust electricity transmission network. First, electricity generation from wind and solar resources is only intermittently available - the sun only shines for part of the day to fuel solar panels, and the uneven atmospheric heating from solar radiation does not generally create steady, all-day winds in specific locales. Second, commercially feasible electricity storage is not currently available. Thus, the electricity generated from wind and solar resources is not always available to meet consumer demand and, when it is, it must be immediately transmitted for consumption otherwise it is wasted. Building additional transmission lines and facilities is one approach to addressing these obstacles. 
I. Planning and Management of the Transmission Grid

The U.S. electricity grid features an estimated 200,000 miles of high-voltage transmission lines and another 5.5 million miles of local distribution lines altogether worth in excess of \$1 trillion dollars. ${ }^{13}$ This system is the network of wires and related facilities on which our modern society depends. The pressing question today is whether the planning and management of this vast infrastructure requires more centralized (federal) control.

\section{Structure of the Grid}

Although the U.S. transmission infrastructure is vast, it is not accurate to reference a single unified national transmission grid. Rather, there are three separate asynchronous grids-the Western Interconnection, the Texas Interconnection, and the Eastern Interconnection-that cumulatively make up the U.S. transmission grid. ${ }^{14}$ This circumstance reflects a fragmented history of monopolistic and vertically-integrated utility companies building and managing transmission facilities to deliver their generated electricity to consumers. ${ }^{15}$ The utilities' respective electricity delivery monopolies ensured a captive market for the sale of their electricity generation: utilities would build the transmission lines and local customers would pay for the construction costs through increases in their monthly electricity charges. State governments acquiesced to these socalled "natural" monopolies and sought to regulate pricing, construction, and management of utility operations. $^{16}$ As time advanced-and utilities merged or formed joint ventures_a wider unsystematic grid began taking shape and eventually developed into three main grids with control of individual transmission facilities residing with the local utility.

13 Electric Power Research Institute, The Green Grid - Energy SAVINGS And Carbon Emission REDUCTIONS ENABLED BY A SMART GRID (2008), available at http://www.smartgridnews.com/artman/uploads/1/SGNR_2009_EPRI_Green_Grid_June_2008.pdf.

14 See, e.g., U.S. Dept. of Energy, Electricity Delivery and Energy Reliability, http://www.eere.energy.gov/de/us_power_grids.html.

15 See, e.g., M. GRANOVETTER, P. MCGUIRE, THE MAKING OF AN INDUSTRY: ELECTRICITY IN THE UNITED States, in Michel CALlon, EDitor, THE LAW OF MARKeTs, Oxford: Blackwell, 1998, pp. 147-173.

16 Id. These were natural monopolies in the sense that the costs associated with creating the transmission infrastructure necessary to provide electricity to consumers were quite high and it was thought inefficient to have consumers pay for duplicative infrastructure from a competing utility. Further, generation capabilities in the early years of electricity generation were decidedly local. As a result, electricity delivery was thought to naturally be the exclusive purview of a single operator, local generation company.

Center for Global Energy, International Arbitration, and Environmental Law 


\section{Towards Regional Management of the Transmission Infrastructure}

Changes to the long-standing utility monopoly arrangement began at the federal level in 1978 but only gained serious momentum in the past decade. ${ }^{17}$ Congress pushed this process by enacting the Energy Policy Act of 1992 with an intent to remove impediments to competition in the wholesale market. ${ }^{18}$ Four years later, in 1996, the Federal Energy Regulatory Commission (“FERC”) responded by issuing Orders 888 and 889 which sought, in part, to provide open access to transmission facilities for all entities, not just those utilities that already owned and supplied generation. ${ }^{19}$ These Orders were intended to provide the foundation for competitive wholesale power markets, in contrast to the monopoly control of the past. ${ }^{20}$ Roughly contemporaneously, many states made a parallel effort to also develop retail competition for electricity consumers by opening up the transmission infrastructure to all generators. Retail competition was similarly intended to foster competition by allowing local customers to choose their electricity provider regardless of their geographic service area within the state. ${ }^{21}$

Three years later, in 1999, FERC looked to extend its earlier efforts at opening the transmission infrastructure by issuing Order 2000. This order encouraged all transmission-owning entities, private or public, to timely place their transmission facilities under the control of a regional transmission organization or an independent system operator. ${ }^{22}$ In its explanation of the new rule, FERC cited its continued concern that the vertically-integrated utilities that owned and controlled transmission facilities were still discriminating against third-party generation companies that needed access to the utilities' transmission facilities in order to deliver electricity to consumers. ${ }^{23}$ FERC's proposed regional management structures were intended to address this concern by providing independent management of the transmission facilities separate from the business of

17 In 1978, Congress passed the Public Utilities Regulatory Policies Act, Pub. L. No. 95-617, which, in relevant part, sought to open the power markets to non-utility producers of energy and required utilities to purchase power from non-utility producers.

18 H.R. 776, Energy Power Act of 2002, Sec. 722.

19 Promoting Wholesale Competition Through Open Access Non-discriminatory Transmission Services by Public Utilities and Recovery of Stranded Costs by Public Utilities and Transmitting Utilities, Order No. 888, 61 FR 21,540 (May 10, 1996).

20 Id.

21 See State of TeXas, OfFicial Guide to Electric Choice, available at http://www.powertochoose.org/_files/_pdf/ConsumerGuide_eng.pdf (In Texas retail electricity consumers can choose their retail electricity provider regardless of their physical location).

22 Federal Energy Regulatory Commission, 18 CFR Part 35 / Order No. 2000 (Dec. 20, 1999), available at http://www.ferc.gov/legal/maj-ord-reg/land-docs/rm99-2-00k.pdf. FERC maintained flexibility for the industry participants to determine how to compose these organizations, although each regional organization was required to meet a minimum number of characteristics, including exhibiting Independence and Operational Authority. Such organizations further were required to perform a minimum number of functions, including Tariff Administration and Design, Congestion Management, and Interregional Coordination.

23 Id. at 2. 
generation. ${ }^{24}$ Regional control was further aimed at increasing connectivity between the various utility facilities and increasing reliability of the system as a whole, as generation resources from across a wider area could be used to balance supply and demand (load). All of these changes were also found to be necessary to create a regulatory structure that would support deregulated electricity sales and encourage competition. ${ }^{25}$

At the time of Order 2000, FERC stated that it held "specific authorities and responsibilities under the Federal Power Act to protect against undue discrimination and remove impediments to wholesale competition," however, it stated that it was favoring a more "open collaborative process that relies on voluntary regional participation to design [regional transmission operators] that can be tailored to specific needs of each region.”26 FERC's deferential position may have been motivated by a philosophical desire to allow different regions to tailor their transmission organizations to local needs, or it may have been a tacit acceptance of the superior legal and political power held by local utilities and state regulators. In either case, the regional organizations called for by FERC remain voluntary, and today, several years later, a number of states and regions-particularly in the West and Southeast-have still not set up a regional transmission operator as FERC envisioned. ${ }^{27}$

The foregoing provides a greatly abridged history of the current balkanized U.S. electricity infrastructure. This somewhat fitful development has resulted in the grid constraints that exist today: interconnection between the three main grids is largely limited to a few low capacity lines, and electricity redistribution between the three different grids is not presently possible. ${ }^{28}$ As a result, generated electricity cannot be balanced between the West, East, and Texas grids. ${ }^{29}$ Further, there exist only seven of the domestic regional transmission operators (regional transmission operators and independent system operators) that FERC encouraged in Order 2000 which manage transmission facilities in their specific geographic regions. ${ }^{30}$ At least one-third of the United States does not contain a regional transmission grid operator at all. ${ }^{31}$ Finally, interconnection between the existing regional operators is limited, so even if multiple regional

Id. at 3 .

Id.

26 Id. at 8-9.

27 THE ISO/RTO COUNCIL, 2009 STATE OF THE MARKETS REPORT at 5 (hereinafter IRC Report), available at http://www.isorto.org/atf/cf/\{5B4E85C6-7EAC-40A0-8DC3003829518EBD\}/2009\%20IRC\%20State\%20of\%20Markets\%20Report.pdf

28 U.S. Energy Information Administration, Energy in Brief - What is the electric power grid, and what are some challenges it faces?, http://tonto.eia.doe.gov/energy_in_brief/power_grid.cfm.

29 Id.

30 IRC Report, supra note_27, at 5.

31 Id. 
operators exist on the same grid (as they do, for example, in the Eastern Interconnection) there is limited interconnection between the regional operators themselves. ${ }^{32}$

In sum, these attributes combine to create a circumstance where certain areas of the country feature mostly deregulated electricity markets with regionally controlled transmission facilities that participate in joint planning efforts for electric transmission infrastructure. In those areas, regional organizations provide more open access to the grid for non-utility electricity generators (like wind and solar farm operators) and play a leading role in the planning and development of new transmission facilities. Other areas of the United States, by contrast, continue to look like the amalgamation of utility-controlled monopolies of forty years ago, with transmission planning primarily focused on individual utility areas.

\section{The North American Electric Reliability Corporation}

The additional issue of risk of grid failure requires mention as it factors into the broader debate as to whether transmission facilities require additional control and oversight from a centralized regulatory body. This risk is heightened as a result of the structure of the current grid which, even though it is highly balkanized, is more tied together than at any point in history. A more interconnected network carries unique risks of failure because demand loads and generation supply must be perfectly balanced across a vast transmission network in order to maintain electricity delivery. ${ }^{33}$ When problems arise with transmission facilities in one part of the grid, this balance can become unstable, causing large swaths of the network to fail, leading to power outages across the grid. ${ }^{34}$ Such concerns are classified within the utility industry as issues falling within the broad category of reliability, and can be exacerbated by the connecting together and balancing of disparate transmission facilities from different utilities.

Addressing this problem of reliability necessitates that utilities determine how to set universallyaccepted standard operating procedures for an interconnected system, in addition to determining how the system itself is constructed. The challenge presented in setting these standards-and gaining broad acceptance on the structure of the future system-is in some respects reminiscent of

32 IRC Report, supra note 27, at 28-31.

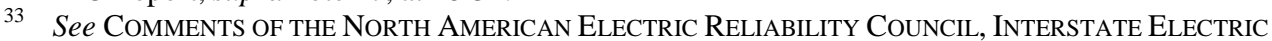
TRANSMISSION SYSTEM ELECTRIC RELIABILITY ISSUES - NOTICE OF INQUIRY at 3-6, available at http://www.nerc.com/docs/docs/pubs/DOE-NOI-comments.pdf (forecasting that a future grid failure was only a matter of time based on the increased risks presented by an increasingly interconnected grid. See footnote 34, below for the realization of that forecast).

34 In 2003, for example, a transmission outage in Ohio caused a cascading failure in the grid that caused outages for 50 million customers running from Michigan to New York and into Canada. The total cost of the outage in the U.S. was estimated at between \$4 billion and \$10 billion. See, U.S.-CANADA PowER SYSTEM Outage Task Force, Final Report on the August 14, 2003 Blackout in the United States and CANADA: CAUSES AND RECOMMENDATIONS, at 1, available at http://www.nerc.com/docs/docs/blackout/ch13.pdf. 
the slow progress being made in establishing regional transmission operators, i.e., independent utilities do not always want to cede control of their business practices to a centralized regulatory entity. This resistance to adopting new standards is reasonable from the perspective of the individual utilities as they presumably have found a set of transmission facilities and operating standards that have worked well enough for their service area. Once the risks are multiplied in an interconnected system, where one outage can shut down a huge network of transmission lines, such individualized protocols may be insufficient.

Congress sought to address this problem of standardization and planning in the Energy Power Act of 2005. Among its other provisions, Congress tasked FERC with the responsibility of designating an Electric Reliability Organization that would establish a set of mandatory guidelines and operating procedures. ${ }^{35}$ Unsurprisingly, FERC chose the North American Electric Reliability Corporation, a non-profit corporation created by utility companies in 1968 to provide voluntary standards of the type that Congress was now requiring to be mandatory. ${ }^{36}$ As reorganized after being designated by FERC, the North American Electric Reliability Corporation is now a selfregulating, non-profit corporation tasked with regulating the bulk power systems in the U.S. and Canada, subject to continuing-and now enhanced-oversight from FERC. ${ }^{37}$ It monitors and forecasts reliability throughout the transmission grid and has the power to levy fines against utilities that do not meet its required operating procedures. ${ }^{38}$

The existence of the North American Electric Reliability Corporation, and its newly found regulatory powers, presents an additional layer of complexity in the debate over the future of planning and management in the transmission grid. While this corporation unquestionably holds the power to set operating standards and levy fines against utilities not meeting its standards, that power may not be enough to ensure reliability in an unsystematically developed grid infrastructure. And, the problem of ensuring reliability will arguably become more difficult as federal and state governments push to add very significant levels of centralized renewable energy resources in the next few years. Incorporating such centralized generation sources onto the grid is not likely possible without significant transmission build-out and far greater interconnection among the current facilities, thus potentially raising risks throughout the system. Separately, the intermittent generation attributes of renewable generation present their own unique problems in maintaining reliability across the grid. Thus, it remains a live question whether a more federally-

35 H.R. 6, Electricity Modernization Act of 2005, amending the Federal Power Act, codified as16 U.S.C. 824 et seq., available at http://www.epa.gov/oust/fedlaws/publ_109-058.pdf.

36 Press Release, National Electric Reliability Council, NERC Approved as the United States Electric Reliability Organization (July 20, 2006), available at http://www.nerc.com/fileUploads/File/PressReleases/PR_072006_NERC_Named_ERO.pdf.

37 See North AMERICAN EleCtric RELIABILITY COUNCIL, 2008 ANNUAL REPORT, at 1-2, available at http://www.nerc.com/files/2008-Annual-Report.pdf.

38 Id. at 3-6.

Center for Global Energy, International Arbitration, and Environmental Law 
controlled grid is necessary to ensure reliability throughout the three grids. The following case example provides a look at what part these problems played in the planning and management of one of those grids, and what implications that experience holds for the rest of the nation.

\section{a) Case Example: Transmission Planning in the Texas Interconnection}

This part analyzes current planning through the prism of the Texas Interconnection. Texas, as mentioned in the introduction, is a unique state in the realm of electricity transmission. It contains a mostly deregulated electricity market with nation-leading renewable energy production and a grid that nearly encompasses Texas but includes no other states. ${ }^{39}$ This nearly single-state area is relevant, in part, because the Federal Energy Regulatory Commission only holds specific jurisdiction to regulate electricity sales within a grid where an electron is likely to have crossed state lines at some point within the transmission process ${ }^{40}$ and, as a result, does not regulate most of the electricity sales conducted within the state of Texas. ${ }^{41}$ Thus, it may be somewhat surprising that seventy-five percent of the land area of Texas is regulated by a single regional transmission operator and market (The Electricity Reliability Council of Texas) of the kind envisioned by FERC when it issued Order 2000. ${ }^{42}$ That concentrated regulatory jurisdiction is likewise matched by the existence of a single state regulatory entity - the Public Utility Commission of Texas. ${ }^{43}$ Most states, even where a regional transmission operator has been established, share an electrical grid and system operator with multiple states, each of which has its own state regulatory entity with its own institutional objectives. ${ }^{44}$ In terms of electricity transmission, Texas truly is close to being its own country, making it a good comparison case for planning issues that are present nationwide.

\section{Texas Renewable Portfolio Standard}

The introduction observed that there is a strong political will to develop centralized renewable generation resources in the United States. One way for legislators to express that will is to pass a Renewable Portfolio Standard which sets a target for the amount - set as an aggregate megawatt

39 See U.S. Dept. of Energy, Electricity Delivery and Energy Reliability, supra note 14.

40 See FERC Order 888, supra note 19, at 38,961 (observing that the interstate commerce question "does not turn on whether the contract path for a particular power or transmission sale crosses state lines, but rather follows the physical flow of electricity”); Florida Power Commission v. Florida Power \& Light Co., 404 U.S. 453, 458, 463 (1972) (finding, where Florida Power \& Light Company was not "directly involved in power exchanges with Georgia," that FERC (then the Federal Power Commission) had jurisdiction because energy from Florida Power \& Light “commingled” with energy from another utility within Florida, which interconnected with Georgia Power Co.).

4116 U.S.C. Sec. 824 et seq.

42 See ElECTRIC RELIABILITY COUNCIL OF TEXAs, 2008 ANNUAL REPORT at 3, available at http://www.ercot.com/content/news/presentations/2009/ERCOT\%202008\%20Annual\%20Report.pdf

43 See Public Utility Regulatory Act, Title II, codified as TeX. Utilities CoDE ANN. Sec. 11.002(c), available at http://www.puc.state.tx.us/rules/statutes/Pura09.pdf.

44 See U.S. Dept. of Energy, Electricity Delivery \& Energy Reliability, supra note 14. 
goal or a specified percentage of all electricity generation —of renewable generation that a state seeks to achieve. Texas's experience with setting a renewable portfolio standard illustrates the process of bridging the divide between a desire for deploying centralized renewable energy on one hand, and the reality and constraints of the existing transmission infrastructure on the other.

In 1999, Texas legislators passed a renewable portfolio standard in Senate Bill 7-which, separately, also sought to introduce competition into the retail electric market—and set a goal for 2,000 megawatts of renewable generating capacity to be installed in Texas by 2009. ${ }^{45}$ Subsequent rapid growth in state-wide renewable energy generation led to the recognition that the goals set in 1999 would be passed well before the target date. As a result, in 2005, Senate Bill 20 was introduced during the $79^{\text {th }}$ Legislative session and set a goal of an additional 5,000 megawatts, on top of the then-existing 880 megawatts of capacity, of new renewable capacity to be installed by $2015{ }^{46}$ It further included a target of 10,000 megawatts of total renewable electricity generation by $2025 .^{47}$

Similar to the experience with the 1999 bill, however, renewable energy development quickly outstripped the state goals. Texas wind developers alone easily surpassed the added requirement of 5,000 megawatts of new renewable generation, and through the third quarter of 2009, Texas held 8,797 megawatts of renewable wind generation capacity. ${ }^{48}$ No further legislative additions to the state renewable portfolio standard have since been enacted although centralized renewable energy development continues apace.

\section{Competitive Renewable Energy Zones}

Perhaps more important than the renewable generation goal was a provision in Senate Bill 20 that directed the Public Utility Commission of Texas to designate so-called competitive renewable energy zones. ${ }^{49}$ The basic idea was that the Commission would establish geographic zones within the state where future transmission facilities would be the built with the intention of sending renewable energy generation (primarily from wind) from windy rural areas to urban load centers. ${ }^{50}$ These legislatively directed zones were the planning mechanism enacted to create a transmission

45 Codified as Tex. Utilities Code AnN. § 39.904 (Vernon supp. 2006).

46 Texas Legislature Online, Senate Bill $20-79^{\text {th }}$ Legislative Session, available at http://www.capitol.state.tx.us/tlodocs/791/billtext/pdf/SB00020F.pdf.

47 Id.

48 AMERICAN Wind ENERgy Association, Q3 MARKET REPORT 2009, available at http://www.awea.org/newsroom/releases/10-20-09_AWEA_Q3_market_report.html.

49 See, Tex. Utilities Code AnN. § 39.904(g).

50 Electricity Reliability Council of TEXas, ANALysis of Transmission Alternatives for COMPETITIVE RENEWABLE ENERGy ZONES In TEXAs, available at http://www.ercot.com/news/presentations/2006/ATTCH_A_CREZ_Analysis_Report.pdf. 
infrastructure robust enough to meet the generation goals set by the legislature in the renewable portfolio standard.

Part of the task for the Commission was to determine the most cost-effective and efficient manner for adding this transmission infrastructure. ${ }^{51}$ In July 2007, after nearly two years of dedicated studies, the Commission announced and subsequently cited by interim order, five regions located in West Texas as the most promising for renewable energy development based on their natural wind conditions and proximity to large load centers (cities). ${ }^{52}$ The interim order called for these five regions to be the site of future renewable energy generation with transmission directed to urban areas such as Dallas/Fort Worth. ${ }^{53}$

Subsequently, the Commission released the process requirements for companies to compete to build the transmission facilities. ${ }^{54}$ On September 12, 2008 a group of utilities filed a joint proposal with the Commission for the purpose of constructing those facilities, including a map of the proposed transmission line routes. ${ }^{55}$ That proposal-viz. ERCOT Scenario 2 CREZ Transmission Plan—was approved by the Commission a few months later on January 29, 2009. ${ }^{56}$ In March of 2009, the Commission issued its Final Order for construction of the 2,334 miles of $345 \mathrm{kV}$ transmission lines. ${ }^{57}$ This is a fast-track project targeted to start in 2010/2011 and set to reach completion by 2013; upon completion, it will add an estimated 18,456 megawatts of capacity to the present system. ${ }^{58}$ It carries a maximum budget of $\$ 4.93$ billion. ${ }^{59}$

The rapidity with which this project was planned and implemented appears to be attributable, in part, to a favorable regulatory circumstance and physical grid structure. In that respect, the Electric Reliability Council of Texas service area provides a benchmark for what a regionally managed grid can accomplish in a short period of time. However, there may be drawbacks in moving so quickly as opposition to part of the plan has formed, an issue that is explored in the case example in section two. At any rate, how Texas's experience factors into the larger debate over additional federal control of the transmission grid is likely subject to interpretation. The

51 Id.

52 See, Electric Reliability Council of TeXas, Competitive Renewable EnERGy Zone Update, at 4, available at http://www.ercot.com/meetings/board/keydocs/2007/B1016/Item_06_-_CREZ_Update.pdf.

53 Id.

54 Barry Smitherman, Chairman, Public Utility Commission of Texas, Report to House State Affairs Committee [hereinafter Smitherman Report], available at http://www.puc.state.tx.us/about/commissioners/ smitherman/present/pp/State_Affairs_022409.pdf.

55 Public Utility Commission of Texas, Docket 35665 - Commission Staff's Petition for Selection of Entities Responsible for Transmission Improvements Necessary to Deliver Renewable energy From Competitive Renewable Energy Zones (September 12, 2008) [hereinafter PUC Docket 35665], available at http://www.clearviewalliance.org/docs/TexasCREZ-ConsortiumCTPfilingdatedSeptember12_2008.pdf.

56 Smitherman Report, supra note 34.

57 Public Utility Commission of Texas, Docket 35665, March 2009.

58 Id. at 3.

59 Id. 
following subpart provides additional context to the question of "federal versus local control" of planning and management by reviewing two recent developments with broad national implications.

\section{b) Recent Developments in Planning}

There are a number of recent developments in this broad area that deserve coverage, but in the interest of brevity only two were chosen. The first recent development describes an effort to increase interconnection between the three U.S. grids that, if successful, may be the first step in constructing a grid that is truly national in operation and management. There is, however, burgeoning opposition to a more national approach to transmission management as certain states worry about being left out of the process, while others seek to sidestep federal regulation and maintain independence. The second development presented highlights different risks and opportunities that exist for individual states even in purely regional planning projects. For both issues, the significant tension centers on which states, utilities, and geographic areas stand to benefit most from the build-out and interconnection of the transmission network.

\section{Tying Together the Three Grids}

On October 13, 2009 Bill Richardson, Governor of New Mexico, formally announced the launch of the Tres Amigas LLC project to tie together the three U.S. transmission grids. ${ }^{60}$ The project seeks to build a 5 GW “superstation” in Clovis, New Mexico that would link the three grids and allow utility companies to buy and sell power in a market provided by the superstation, and then route that electricity to customers throughout the nation. ${ }^{61}$ As promised, the 22.5 square mile superstation would provide additional markets for renewable energy generation nationwide, allowing renewable energy generated in one grid to be shipped anywhere in the nation where it was needed. ${ }^{62}$

Whether or not the Tres Amigas project is ultimately built, the obstacles that confront the project—as well as the problems it seeks to solve-roughly represent several of the political and regulatory problems facing wide-spread interconnection. First up, on the issue of regulation, the project presents the question of whether the Electricity Reliability Council of Texas ("ERCOT”) service area (covered in the case example) could participate in an interconnection project without

60 Press Release, State of New Mexico Governor Bill Richardson, Clovis-Area Superstation To Send NM-Produced Renewable Energy to Customers in Other States (Oct. 12, 2009), available at http://www.governor.state.nm.us/press/2009/oct/101209_01.pdf

61 Electric Power Research Institute, Discussion Materials - The Tres Amigas Superstation ProJeCt, available at http://www.tresamigasllc.com/docs/epri-discussion.pdf (the discussion materials note interesting regional grid integration planning efforts in China and Europe).

$62 \quad$ Id. at 12. 
coming under the jurisdiction of FERC. As covered above, FERC does not regulate most of the bulk electricity sales in the ERCOT service area because electricity is not shipped across state lines. ${ }^{63}$ The Tres Amigas project is located in New Mexico which could cause part of the ERCOT market to come under FERC jurisdiction.

Tres Amigas LLC sought to address this obstacle by filing a Petition for Disclaimer of Jurisdiction with FERC on December 8, 2009. ${ }^{64}$ The petition asked that FERC not exercise jurisdiction over the new project on the basis of one of three rationales: (1) by finding that the interconnection does not constitute interstate commerce, (2) determining that the design of Tres Amigas does not commingle interstate electricity and ERCOT would continue to be a wholly separate electrical grid, or (3) allowing an exemption from jurisdiction under the Federal Power Act. ${ }^{65}$ In providing policy support for the petition, the first benefit listed is "providing the developers of renewable (and other) generation expanded markets in which to sell their power." ${ }^{66}$ It continues on to state that "this benefit is particularly important because Tres Amigas will be located adjacent to areas of the country that have been identified as among the most promising from the standpoint of developing renewable wind, solar and geothermal power." ${ }^{67}$ The best wind resources in the nation are located along the central United States running from North Dakota down to Texas, and the West holds the greatest potential for solar and geothermal generation. ${ }^{68}$

On March 18, 2010 FERC approved Tres Amigas' request for authorization to sell transmission services at negotiated rates but declined the petition to disclaim jurisdiction. ${ }^{69}$ The decision to keep jurisdiction over the project was not an absolute rejection of the petition; instead, FERC narrowly based its rejection on a lack of specific information on how the project would function. ${ }^{70}$ Thus, there remains a strong possibility that FERC could later disclaim its jurisdictional claims over the ERCOT market, although the project still faces a long road to construction and implementation. Ironically, the second listed benefit of the project-close proximity to promising natural resources and development of a nationwide transmission capability-may presage a potential political battle for the Tres Amigas project and other similar future interconnection attempts. From a national interest perspective, the production of renewable energy generation is

63 See 16 U.S.C. Sec. 824 et seq.

64 Federal Energy Regulatory Commission, Docket No. EL10, Petition for Disclaimer of Jurisdiction of Tres Amigas LLC, available at http://www.tresamigasllc.com/docs/Tres-Amigas-petition-for-disclaimer.pdf.

65 Id. at 2-3.

66 Id. at 5.

67 Id.

68 See National Renewable Energy Laboratory, United States Atlas of Renewable Resources, http://www.nrel.gov/gis/maps.html\#resource_atlas.

69 Press Release, Federal Energy Regulatory Commission, FERC Approves Negotiated Rates for Tres Amigas Transmission Project (Mar. 18, 2010), available at http://www.ferc.gov/news/newsreleases/2010/2010-1/03-18-10-E-11.pdf.

70. 
arguably best achieved by concentrating generation resources on the geographic areas where generation is the most productive and cost-effective. But for some states not located in an area with great renewable potential, a more important goal may be to protect state electricity markets from outside competition and not miss the opportunity for job growth and technological leadership associated with state-based renewable energy generation.

Analogous concerns were raised in May of 2009 when a group of eleven governors sent a letter to Congress opposing the development of a system of high-voltage transmission lines running from the Midwest to the East to deliver low-cost renewable energy (a topic covered in the next section on siting). ${ }^{71}$ The letter argued for local control and regional planning, rather than a nationwide approach to solving electricity transmission limitations. ${ }^{72}$ In the letter, the governors cited as a key concern that federal funds would be used to subsidize the build-out of this infrastructure, thereby undercutting states' ability to competitively develop local offshore wind resources. ${ }^{73}$

The governors' arguments appear to be a strong reproach to certain federally subsidized infrastructure projects that undercut state projects. However, that argument does not clearly relate to a privately funded project like Tres Amigas, as it is neither subsidized nor proposed to directly impact ratepayers. In that respect, the Tres Amigas project may provide an interesting litmus test as to whether state governments will support a national goal of generating the lowest-cost renewable energy generation available, or seek to pursue more regional interests.

\section{High Stakes for States in Regional Planning}

Even states that possess great renewable energy resources face risks in the regional planning of transmission construction. A significant controversy in the Southwestern Power Pool-the regional transmission operator for the states of Kansas, Nebraska and parts of seven other states $^{74}$ - during the last half of 2009 highlights one of those risks. The issue present in the Southwester Power Pool, much like the one faced in Texas, was where to build transmission facilities that would be used to transport renewable energy generation from rural generation points to urban load centers. ${ }^{75}$ Unlike in Texas, however, the Southwestern Power Pool covers several

\footnotetext{
71 Letter of the Eastern Governors on Renewables and Transmission Planning, Addressed to United States Congress (May 11, 2009), available at http://energycommerce.house.gov/Press_111/20090612/testimony_hibbard.pdf.

72 Id. at 2.

73 Id.

74 Southwestern Power Pool, Fast Facts at 2, available at http://www.spp.org/publications/SPP_Fast_Facts.pdf.

75 See SOUTHWESTERn POWER POOL, NEXT STEPS FOR EHV Overlay at 20, available at http://www.spp.org/publications/SPPT-BKGD020609.pdf.
} 
states and must balance the political interests of all of these states against any proposed technical recommendation for transmission construction.

The timeline of the controversy developed as follows. In April of 2009, the Southwestern Power Pool announced its list of priority planning projects-those transmission facilities that were slated to be built in the very near-term. ${ }^{76}$ This construction was intended to increase transmission reliability across the territory and encourage the development of renewable energy generation resources throughout the service area. ${ }^{77}$ One of the six initially listed projects-the "SpearvilleKnoll-Axtell” line-was a 215 mile, 765kV line projected to run from southwest Kansas north up to Nebraska and carried a construction cost of $\$ 237$ million. ${ }^{78}$

The board of the Southwestern Power Pool, however, removed this project from the priority list in early October of 2009, thereby eliciting a letter of concern from the Governor of Kansas, Mark Parkinson. ${ }^{79}$ In the letter the governor encouraged the board of the Southwestern Power Pool to reevaluate their decision and emphasized the importance of the project to the development of Kansas's wind resources. ${ }^{80}$ The Spearville-Knoll-Axtell line was thought to be especially important because the best wind resources in Kansas are located in the sparsely populated western part of the state where the line would run. A few weeks after the governor's letter, the board of the Southwestern Power Pool re-released its list of proposed priority projects and, this time, the Kansas line was again included. ${ }^{81}$

This local controversy carries broader implications because it highlights the circumstance that centralized renewable energy development is mostly a zero-sum game in the short-term, i.e., there are many magnitudes more of potential renewable energy generation in the United States than can be consumed, and even less renewable generation that can be transmitted with current transmission capacity limits. ${ }^{82}$ Here, Kansas would have lost a state construction project worth $\$ 237$ million, much of which would have been paid for by increases on the ratebase of electricity

76 Press Release, Southwestern Power Pool, Portfolio of New EHV Transmission Projects Approved: Benefits Will Be Balanced Across SPP Region (April 29, 2009), available at http://www.spp.org/publications/Transmission_Project_Portfolio_Approved_4_29_09.pdf.

77 Id.

78 Id.; ITC Great Plains, Capital Project Profile - Spearville to Knoll to Axtell Project (KETA PROJECT), available at http://www.itcgreatplains.com/pdfs/projects/ska/ITCGP_Profile_KETA_Gen.pdf.

79 Press Release, State of Kansas Governor Mark Parkinson, Governor urges Southwest Power Pool to make transmission project in Kansas a priority (October 22, 2009) (on file with author).

80 Id.

81 Press Release, Southwestern Power Pool, SPP Priority Transmission Projects Endorsed Pending Further Study, available at http://www.spp.org/publications/SPP_Priority_Projects_Endorsed_10_27_09.pdf.

82 See, e.g., National Renewable Energy Laboratory, Renewable Resource Data Center, Energy Tidbits at http://rredc.nrel.gov/tidbits.html [Last Visited November 28, 2009]. 
customers outside the state. ${ }^{83}$ More fundamentally, the state would miss an opportunity to become an established source of renewable energy generation, including gaining the future construction projects necessary to build more generation, rather than importing energy from another state. That is the same type of concern, albeit in a different context, from that expressed by Eastern state governors over the build-out of a national transmission infrastructure.

Both Tres Amigas and the Kansas high-voltage power line projects illustrate the high stakes for states in the ongoing transmission build-out. The friction present in these projects directly concerns what level of government—or what administrative body—will be making the decisions that determine the future of energy development in individual states. A similar type of conflict is present in decisions on where to place the physical facilities, and on whose land. The next section examines the issues surrounding siting of transmission facilities.

\section{Planning and Siting Transmission Facilities}

As might be expected, determinations regarding the physical siting (placement) of transmission facilities contain a strong federal-state tension similar to the one present in planning, as planning and siting to some degree go hand-in-hand. In particular, there is a continuing national debate concerning whether siting determinations-where to place the actual transmission facilitiesshould continue to be exercised at the state level or whether the Federal Energy Regulatory Commission should be granted new jurisdiction and power over those decisions. The established policy has been that individual state authorities assumed all jurisdiction to approve or deny permits for the siting and construction of electric transmission facilities, which is one reason why the "national grids" are really only an aggregation of state-approved lines and facilities. That arrangement is currently under scrutiny and it is a matter of contention between federal and state authorities whether increased grid reliability and rapid grid construction require a centralized federal siting authority.

\section{The Controversy over National Interest Electric Corridors}

The roots of the current debate over siting jurisdiction were set when Congress passed the Energy Policy Act of 2005, which in part amended section 216 of the Federal Power Act. ${ }^{84}$ As amended, Section 216 directed the Secretary of the Department of Energy to identify congestion and

83 See Southwestern Power Pool, Next Steps for EHV Overlay, supra note 76; Press Release, Southwestern Power Pool, SPP Priority Transmission Expansion Projects Endorsed, Pending Further Study, available at http://www.spp.org/publications/SPP_Priority_Projects_Endorsed_10_27_09.pdf.

84 Section 216(a), Federal Power Act; Section 1221(a), Energy Policy Act of 2005, Codified as 16 U.S.C. § 824p(a). 
constraint problems in electricity transmission throughout the nation. ${ }^{85}$ Constraints are the physical or operational barriers that dictate how much electricity each part of the grid can transmit. ${ }^{86}$ Congestion problems, by contrast, roughly refers to limitations in the actual or scheduled electricity shipments across a particular part of the transmission infrastructure. ${ }^{87}$ Although constraints exist in all parts of the grid, they carry special importance in areas where the amount of electricity that needs transmitting far outstrips the capacity of the grid infrastructure-if the constrained part of grid cannot handle this electricity then more costly congestion problems result. $^{88}$

Under Section 216(a), the areas that the Secretary of Energy identified as congestion and constraint problems could receive the designation of "national interest electric corridors." Such a designation represented a planning decision in the transmission infrastructure, even though it only indicated the broad areas where the Department of Energy thought future transmission facilities should be built. The Secretary of Energy subsequently announced two corridor designations in October of 2007: (1) the Southwest Area National Corridor, which covers a wide swath of Southern California and part of Western Arizona, and (2) the Mid-Atlantic Area National Corridor, which covers most of the eastern seaboard from upstate New York down to Virginia, and parts west to Ohio. ${ }^{89}$

These designations did not lack for controversy for several reasons, foremost because transmission planning had always resided with state authorities, not the federal government. Although the Department's corridor designations did not preempt state action, they were interpreted as an opening salvo in determining whether FERC would begin gaining control over the placement and planning of future transmission developments. The Mid-Atlantic corridor, in particular, stirred fierce controversy because of the significant potential of this line to degrade the environmental and scenic beauty along its route. ${ }^{90}$ That route was proposed to run through areas that are subject to long-term conservation easements, raising questions as to the relative value of land and cultural

85 See 16 U.S.C. § 824p(a)(2).

86 See, e.g., U.S. Department of EnERgy, NATIONAl Electric Transmission Congestion Study EXECUTIVE SUMMARY, available at http://www.oe.energy.gov/DocumentsandMedia/NETC_ExSum_8Aug08.pdf.

87 Id. at 1 .

88 Id. at 1-2. For example, if a low cost energy source can not be deployed to meet demand because the capacity of a segment of the transmission infrastructure is limited, other resources much be pulled from other generation sources.

89 See U.S. Department of Energy, National Electric Transmission Corridor Report and the Ordered National Corridor Designations, http://nietc.anl.gov/nationalcorridor/index.cfm.

90 See Nancy A. McLaughlin, Condemning Conservation Easements: Protecting the Public Interest and Investment in Conservation, 41 U.C. DAVIS L. REv. 1897 (2008); Nancy McLaughlin, Condemning Open Space: Making Way for National Interest Electric Transmission Corridors (Or Not) 26 VA. ENVTL. L.J. 399 (2008). Land subject to conservation easements is often attractive to environmentalists and energy companies for the same reason: because it is large and contiguous with limited development. These attributes can provide a "path of least resistance" for transmission companies because of the sparse population densities. 
conservation versus the need to ensure grid reliability and increase renewable energy potential. ${ }^{91}$ There were also general concerns that a federally-controlled process would not include the same level of public comment and participation as compared with more local approaches, especially since the federal planning decisions would lie with a politically un-accountable administrative agency far removed from the influence of local representatives.

\section{The National Interest Electric Corridor Controversy Continued - Litigation over Siting Authority}

As controversial as the idea of the national interest electric corridors was, the power to approve siting within the corridors was the real game. According to Section 216, FERC was provided with the power to approve transmission construction permits within national interest electric corridors that it had designated - if the relevant state authority had not acted on the permit application for over one year after the filing, or was unable to act upon the application. ${ }^{92}$ Although this was a significant new grant of power, both state regulatory bodies and FERC seemingly agreed on the meaning of this portion of the statute. State authorities could still deny any transmission project permits that did not meet their criteria.

A little over a year later, in November of 2006, FERC issued its official rule interpretation for Section 216 that deviated from the common understanding. ${ }^{93}$ Under FERC's official rule interpretation, Section 216 actually gave it much broader jurisdiction to approve transmission projects within the national interest electric corridors, even where a state authority had already denied a construction application. ${ }^{94}$ Thus, instead of having what is referred to as "backstop" siting authority to approve transmission facilities where a state entity had not acted, FERC argued that Congress actually gave it the final decision making power for approval of new transmission facilities within its designated corridors. ${ }^{95}$ This was a contentious interpretation of the statute that would significantly alter the balance of power between FERC and the respective state regulatory bodies. If this interpretation won out, FERC would have the power to plan the transmission network through electric corridor designations, and the power to approve permits for construction within those corridors-FERC would essentially control the whole transmission development process.

Two state regulatory entities and two community interest organizations challenged FERC's rule interpretation and, after FERC ruled against them, were joined by many other petitioners in suing

\footnotetext{
91 Id. Everything from civil war battlegrounds to national conservation preserves are included in the designated areas.

9216 U.S.C. $\S 824 \mathrm{p}(\mathrm{b})(\mathrm{C})(\mathrm{i})$.

93 Regulations for Filing Applications for Permits to Site Interstate Electric Transmission Facilities, 119 FERC P 61,154 (2007).

94 Id.

95 Id.
} 
FERC in federal court. ${ }^{96}$ The $4^{\text {th }}$ Circuit received the resulting consolidated litigation, styled as Piedmont Environmental Council v. FERC. In Piedmont, the primary argument regarded the statutory language that granted FERC authority to approve siting permits where a state had "withheld approval for more than 1 year after the filing of [a permit] application."97 FERC argued that the word "withheld" used in this language also included the meaning "denied," while the petitioners argued that such an interpretation violated the plan meaning of the statute. ${ }^{98}$ The $4^{\text {th }}$ Circuit found that FERC's interpretation was nonsensical in the context of the statute and swiftly ruled for the petitioners on the question of siting authority; on January 19, 2010, the Supreme Court declined to review the $4^{\text {th }}$ Circuit's decision. ${ }^{99}$

\section{The Immediate Aftermath of the Piedmont Litigation}

The 4th Circuit's Piedmont decision was rendered in February of 2009 but the court ruling only marked ground in the larger battle. A month later, the acting chairman of FERC, Jon Wellinghoff, testified before the Senate Committee on Energy and Natural Resources asking that FERC be granted the siting powers it had argued before the $4^{\text {th }}$ Circuit that it already held. ${ }^{100}$ Chairman Wellinghoff argued that the national objectives of greatly increasing renewable energy generation and ensuring grid reliability required a federal approach to planning, siting, and cost allocation. ${ }^{101}$ In his testimony, Chairman Wellinghoff did not dispute the need to concurrently develop distributed generation sources — such as regional and local geothermal, solar, and wind-but instead argued that a national infrastructure program was also needed. ${ }^{102}$

Following the Chairman's congressional testimony, in May of 2009, a group of eleven governors from Eastern states running from Maine to Virginia wrote an open letter to Congress arguing against providing FERC with the power to determine planning and siting decisions. ${ }^{103}$ In the letter, the governors strenuously objected to a national transmission infrastructure that shipped

96 Piedmont Envtl. Council v. FERC, 558 F.3d 304 (4th Cir. 2009).

97 Id. at 312 .

98 Id. at 313.

99 Edison Electric Institute v. Piedmont Environmental Council, U.S., No. 09-343, certiorari denied, $1 / 19 / 10$.

100 Testimony of Acting Chairman Jon Wellinghoff, Federal Energy Regulatory Commission Before the Committee on Energy and Natural Resources, United States Senate, Hearing on Legislation Regarding Electric Transmission Lines (March 12, 2009), available at http://www.ferc.gov/eventcalendar/Files/20090312100013-03-12-09-testimony.pdf.

101 Id. at 2-3.

102 Id. at 2 ("Certainly, developing local renewable energy and distributed resources is also important as we expand our capacity to generate clean power, but that is a separate issue from, and is not a substitute for, developing the EHV transmission infrastructure that I describe above and the related feeder lines that will interconnect renewable energy resources to the transmission grid.”).

103 Letter from the Eastern Governors on Renewables and Transmission Planning, Addressed to United States Congress (May 11, 2009), available at http://energycommerce.house.gov/Press_111/20090612/testimony_hibbard.pdf. 
power from the Midwest to the East Coast but would be paid for by customers throughout the nation. ${ }^{104}$ The governors argued that such a system would constrict their states' ability to develop renewable energy resources. ${ }^{105}$ Instead, the governors voiced support for a regionally-controlled approach to developing electricity generation that would allow their states to move forward with their own generation projects. ${ }^{106}$ In June of 2009, Paul Hibbard, the Chairman of the Department of Public Utilities for Massachusetts, echoed these arguments in testimony to two key congressional committees, adding the argument that a national grid system to ship power from the Midwest to the East Coast—paid for by all customers—was anathema to free market capitalism and open competition. ${ }^{107}$

\section{The Legislative Outlook for Planning \& Siting Jurisdiction}

The outcome of this legislative politicking is not yet clear as the details of a new climate bill being drafted by John Kerry, Lindsey Graham, and Joseph Liberman have not, at the time of this writing, been released; the bill is expected to be introduced in April of 2010. ${ }^{108}$ As a point of reference, the previous failed climate bill submitted by Senators Barbara Boxer and John Kerry did not address FERC's siting and planning jurisdiction at all, ${ }^{109}$ whereas a likewise defeated competing house climate bill written by Representatives Henry Waxman and Edward Markey would have significantly amended Section 216 of the Federal Power Act. ${ }^{110}$ The Waxman/Markey bill contained language that directed FERC to establish national electricity grid standards and support and participate-if invited—in the regional planning processes conducted by regional planning entities. ${ }^{111}$

Transmission planning under the Waxman/Markey bill would have still developed from subregional requirements and plans reflecting individual utility service areas, although FERC would have been tasked with the job of coordinating and integrating those plans into regional plans up to national plans. ${ }^{112}$ Future transmission planning would have likely required additional involvement by FERC—and new opportunities for FERC to participate in planning decisions when asked—but

\footnotetext{
104 Id.

105 Id.

106 Testimony of Paul J. Hibbard, Chairman of Public Utilities, Commonwealth of Massachusetts, before the House Subcommittee on Energy and Environment, Committee on Energy and Commerce, available at http://energycommerce.house.gov/Press_111/20090612/testimony_hibbard.pdf.

107 Id.

108 Kevin Sieff, Senators Work on Bipartisan Climate Bill, Financial Times Online (Mar. 29, 2010).

109 See Clean Energy Jobs and American Power Act, S. 1733, (2009), available at http://kerry.senate.gov/cleanenergyjobsandamericanpower/pdf/bill.pdf.

110 See American Clean Energy and Security Act of 2009, H.R. 2454 (2009), Subtitle F - Transmission Planning at 172, available at http://frwebgate.access.gpo.gov/cgibin/getdoc.cgi?dbname=111_cong_bills\&docid=f:h2454pcs.txt.pdf.

111 Id. at 173.

112 Id. at 178.
} 
overall the process would have remained largely controlled by individual states. How that would have affected the incorporation of the national electricity grid standards is uncertain. The Waxman/Markey bill would also have given FERC additional power to approve applications for transmission construction in states located in the Western Interconnection but nowhere else in nation. ${ }^{113}$ FERC could have authorized transmission construction projects even where an individual state authority denied the application, but the bill provided limitations on this power, including that the project must be a multi-state facility. ${ }^{114}$

Forecasts on how the climate change debate will factor on FERC's siting power remain speculative. Whether the current climate bill reflects the Waxman/Markey provisions concerning FERC's jurisdiction is uncertain. At present, what can be said is that FERC only holds "backstop" siting power for determining the location of new transmission facilities and cannot override a state authority's denial of a construction permit. ${ }^{115}$ The debate over the actual content of the climate bills will determine whether this circumstance changes, along with many others.

\section{Eminent Domain and the Transmission Build-out}

A separate level of tension exists for individual landowners in the siting of electrical transmission facilities, as much of the land that is needed for huge infrastructure projects must be condemned and taken by eminent domain. Energy easements are a classic example of a private-to-private land taking, in which energy companies are empowered, under the Federal Power Act, to take privately-owned land. ${ }^{116}$ Unless state law grants relief, the landowner still has to pay taxes on the condemned land, while the energy company-which received the land via government sponsorship-does not. ${ }^{117}$

FERC does not keep official figures tracking the amount of land taken by energy companies through the facility of eminent domain. The use appears pervasive, however, even in projects FERC cites to illustrate the insignificant use of eminent domain. For example, FERC highlights one specific project on its website where a 700-mile gas line that ran primarily over public lands only required a little over $1 \%$ of the land to be taken via eminent domain. ${ }^{118}$ In practice, this

113 Id. at $180-181$

114 Id. at 180.

115 See Piedmont Envtl. Council, 558 F.3d 304, at 320.

11616 USCS § 824p(e) (Federal Power Act § 216 was codified by the Energy Power Act of 2005).

117 If there is any conflict between local zoning laws and the transmission line siting, the Federal Energy Regulatory Commission's interpretation trumps local law. If there is a problem with erosion or maintenance of the right of way, FERC directs affected landowners to contact the energy company first. See 16 USCS § 824p(e); Federal Energy Regulatory Commission, A Guide to the FERC ElECtric Transmission FACILITY PERMIT PROCESS at 9 (on file with author).

118 Federal EnERgy Regulatory Commission, A Guide to the FERC EleCtric Transmission FACILITY PERMIT PROCESS at 2 (on file with author). 
means that the project still required over 7 miles of eminent domain takings for what was, primarily, a gas line built over public lands.

As in other circumstances where eminent domain is a near certainty, private landowners are aware that declining to sell their property outright will lead to a forced sale. This helps to ensure that actual takings through eminent domain are more limited, as landowners know they cannot ultimately prevent their land from being taken. Although federal law requires that "fair market compensation" be paid to the landowner, the purchase amount is negotiated in the shadow of the power of eminent domain. ${ }^{119}$ If the owner insists on too high of a price and cannot agree with the energy company, the land will be taken by force of eminent domain, and the purchase price will be administratively determined. The land taken for transmission infrastructure is substantial—on average, a utility easement for a high-voltage transmission line will be one hundred and fifty feet wide and will carry significant use and access restrictions. ${ }^{120}$ Opposition to forced sales and eminent domain are just one reason why landowners seek to oppose some transmission construction projects, as the following case example illustrates.

\section{a) Case Example: Siting Opposition in the Texas Interconnection}

As described in the first part of the Texas case example, the Public Utility Commission of Texas was tasked by the legislature with determining the best location to build transmission facilities for the transport of renewable energy generation. ${ }^{121}$ The Commission subsequently conducted nearly two years of studies and eventually designated five regions as being the best suited for renewable energy generation and transmission to urban load centers. ${ }^{122}$ A group of utilities then submitted a proposal for building those facilities, including the proposed routes of the transmission facilities. $^{123}$ The Commission accepted that proposal and a construction timeline was set that was to begin in late $2009 .^{124}$

That preliminary planning process and construction timeline did not survive the actual implementation, which required the taking of private land through the use of forced buyouts, or the use of eminent domain, in order to build the actual transmission facilities. ${ }^{125}$ Instead,

11916 USCS § 824p(f).

120 The average width of utility easements for transmission infrastructure line projects is between 100 and 200 feet. Federal Energy Regulatory Commission, A Guide to the FERC EleCtric Transmission FACILITY PERMit PROCESs, at 9 (on file with author).

121 See ElECtRicity RELIABILITy COUNCIL OF TEXAs, ANALysis of Transmission Alternatives FOR COMPETITIVE RENEWABLE ENERgy ZONES IN TEXAs, supra note 50.

122 See, Electric Reliability Council of TeXas, Competitive Renewable EnERgy Zone Update, at 4, supra note 50.

123 See Smitherman Report, supra note 34.

124 See PUC Docket 35665, supra note 55.

125 Id. 
numerous land owners and environmental groups opposed some of the proposed routes based on concerns for scenic integrity and the threat of environmental degradation. ${ }^{126}$ Calculated from the number of miles of transmission lines and the required 200 foot right-of-ways, it is estimated that 56,581 acres of wildlife habitat will be affected by this project. ${ }^{127}$

Not all of the transmission facilities are slated for construction in highly sensitive areas, and there are several utilities building the different segments of the project. Because of the divergent projects and impacts, the Public Utility Commission split its regulatory docket covering the total project into several individual dockets that each has unique concerns. ${ }^{128}$ For instance, the Texas Hill Country transmission route-located in the scenic McCamey area of West Texas-is being built by the Lower Colorado River Authority. ${ }^{129}$ That particular route cuts through a culturally and environmentally important part of the state ${ }_{2}$ and opposition to the route has been strong. ${ }^{130}$ Not only is the specific route a matter of dispute but also the type of facilities-e.g., monopole versus lattice towers - that are to be implemented is a point of disagreement. ${ }^{131}$ At present, the Public Utility Commission has stated that it will review the proposed route proposal in July of 2010, thereby pushing back its original deadline by several months. ${ }^{132}$

As discussed in the first section on planning, the rapidity with which this project was approved is, in part, due to the stream-lined regulatory structure in the state of Texas. That rapid deployment potentially carries a cost, however, as it risks disenfranchising members of the public that would be likely to form opposition groups. For residents and businesses in the tourist destination of the Texas Hill Country there is great importance in where the transmission facilities are located in the current construction-and how those facilities will look when completed-because their appearance is likely to be a part of the landscape well into the foreseeable future. Although these issues are contentious, they are not strictly intractable. Spending money on better looking facilities and less intrusive transmission routes would alleviate a good deal of the opposition. The difficulty lies in allocating the financial and aesthetic burden of these projects onto the respective interested parties.

126 Id.

127 Lorie Woodward Cantu, Texas High Wires - A Balancing Act for Private Landowners, TEXAs WILDLIFE at 26 (July, 2009), available at http://texas-

wildlife.org/files/Texas\%20High\%20Wires\%20article,\%20electronic\%20copy,\%206-12-09.pdf.

128 Public Utility Commission of Texas, Docket 35665, Item 1391.

129 Public Utility Commission of Texas, Docket 35665, Item 1395.

130 See, e.g., Clear View Alliance, http://www.clearviewalliance.org/; Save Our Scenic Hill Country Environment, http://www.soshillcountry.org/index.html; Hill Country Alliance, http://hillcountryalliance.org/HCA/Home; Save the Lampasas River, http://www.savethelampasas.org/.

131 See Bill Neiman, Monopoles Versus Lattice Towers: LCRA Ignores Public's Request, CLEARVIEW ALLIANCE, available at http://www.clearviewalliance.org/docs/MonopolesversusLatticeTowersfinal.pdf (citing the use of monopoles in other transmission installations in Texas and throughout the nation).

132 Id. at 2. 


\section{b) Other Recent Developments in Siting}

The following two developments were chosen because, in addition to being timely, they further illustrate the contrast between the sometimes divergent goals of local communities and the state and federal agenda for increasing potential renewable energy development. That development is important, as it necessarily results in new transmission facilities in the short-run.

\section{Scenic Integrity Issues}

In October of 2009, the Kansas Supreme Court released an opinion in a controversy concerning whether the county of Wabaunsee could ban the placement of "Commercial Wind Energy Conversion Systems” (large commercial wind farms) within county lines. ${ }^{133}$ The plaintiffs' side of the action featured land owners who had entered into written contracts for the development of commercial wind farms, as well as interveners who owned wind rights throughout the county. ${ }^{134}$ The defendants were the three members of the Board of County Commissioners that created the zoning regulations banning the creation of commercial wind farms. ${ }^{135}$

The chronology of the dispute began in 2002, as the county zoning administrator reported to the Board of County Commissioners that there was a company interested in building a commercial wind farm in the county. ${ }^{136}$ Like many counties throughout the nation, Wabaunsee did not have any zoning regulations specifically treating wind farms, so the Board decided to place a moratorium on development, and soon thereafter it directed the county planning commission to review and recommend updates to the County Comprehensive Plan. ${ }^{137}$ One of the recommendations in the updated Comprehensive Plan was "[to] maintain the rural character of the county with respect to its landscape, open spaces, scenery, peace, tranquility, and solitude.”138 That recommendation carried special meaning because Wabaunsee County is the site of part of the Flint Hills, a culturally and environmentally significant location where much of the remaining virgin Tallgrass Prairie in the U.S still exists. ${ }^{139}$

133 See Zimmerman v. Bd. of County Comm'rs, 218 P.3d 400 (Kan. 2009), also available at http://www.kscourts.org/Cases-and-Opinions/Opinions/SupCt/2009/20091030/98487.pdf.

134 Id.

135 Id.

136 Id. at 405.

137 Id. at $405-406$.

138 Id. at 406.

139 See, e.g., Verlyn Klinkenborg, Splendor of the Grass, NATIONAL GeOGRAPHIC, April 2007, http://ngm.nationalgeographic.com/2007/04/tallgrass-prairie/klinkenborg-text; Betsy Rubiner, Old Kansas, Still Growing Tall, N.Y. Times, May 4, 2007, http://travel.nytimes.com/2007/05/04/travel/escapes/04American.html?8dpc. At one time, over 140 million acres of prairie covered the U.S. but only $4 \%$ of that amount is still estimated to exist and most of that amount exists in the Flint Hills. 
In April of 2004, after the planning process, the Board adopted the planning commission's recommendations and scheduled a separate meeting to discuss amending specific zoning regulations regarding small and commercial wind farms. ${ }^{140}$ After that meeting, in June, the Board accepted the regulations proposed by the county planning commission for small wind turbines (distributed wind turbines intended for single-home use) but overrode the planning commission's proposed regulation of commercial wind farms. Instead of agreeing to regulate, the Board voted 2-1 to entirely prohibit commercial turbines from being placed within the county, citing several reasons, including that the turbines would be "incompatible with the rural, agricultural, and scenic character of the County." ${ }^{141}$

Plaintiffs subsequently sued the Board on a number of different theories. These included that the regulation was unreasonable, or that it represented a taking under the Fifth Amendment of the U.S. Constitution. ${ }^{142}$ The interveners later sued on the additional theory of "inverse condemnation," i.e., a theory that the Board's regulation banning placement of wind turbines was so severe that they prevented the interveners from using their property for any economically beneficial purpose. $^{143}$

On October 30, 2009, the Kansas Supreme Court released its opinion in which it found that the Board's decision to ban commercial wind turbines easily met the reasonableness standard. Although the court declined to state its standard of review, it did state that the Board was within its power to base their land use decision on the basis of aesthetics/scenic integrity and the wishes of some residents. ${ }^{144}$ The takings and inverse condemnation claims are still pending as both parties have been invited to give oral arguments on these U.S. constitutional matters; in all other matters the Board was successful. ${ }^{145}$

The Zimmerman case addresses several interesting issues for renewable energy and, potentially, for large-scale transmission line build-out. In short, the Kansas Supreme Court found that a county could ban an energy generation source on the basis of a land use ordinance. Whether a similar land use ordinance could prevent transmission facilities from being installed is uncertain. Generation is arguably a more local endeavor that does not affect a wide area, whereas transmission facilities, especially at the current time, are the tie that connects vast areas. On the other hand, there exists a strong argument that a state or local area should have the flexibility to determine how to meet its energy demands and not be forced into supporting the nation's

140 Zimmerman, 218 P.3d 400 at 406.

141 Id.

142 Id. at 409.

143 Id. at 408.

144 Id. at 416.

145 Id. at 431-432. 
transmission infrastructure at the expense of local cultural and environmental assets. That desire for some local control over new infrastructure projects is analogous to the concerns expressed by Eastern state governors in opposition to the national corridor project, discussed above.

As a practical matter many of these concerns may end up being isolated to culturally or environmentally sensitive projects. The recent development of the governor of Kansas fighting to keep a high-voltage transmission line project in state (discussed in section one) may typify the need for states to compete for huge infrastructure projects in order to gain the construction jobs, tax revenues, and opportunity to export energy. Because of the strong economic considerations, it is nearly a forgone conclusion that the transmission build-out will result in tens of thousands of miles of previously open space being crisscrossed with high-voltage power lines. The lines themselves may need to bend their path, however, in deference to local opposition.

\section{New Siting Process on Federally Owned Land}

Local opposition is less of an issue when the federal government owns all of the land in question. It is not surprising, therefore, that a new and different process for siting transmission facilities on federal lands was announced in October of 2009. This parallel process came about in the form of a Memorandum of Understanding ("Memorandum") signed by the Departments of Defense, Energy, Agriculture, Interior, and Commerce, and the Council on Environmental Quality, the Federal Energy Regulatory Commission, the Environmental Protection Agency, and the Advisory Council on Historic Preservation. ${ }^{146}$ The purpose behind the Memorandum is to stream-line the administrative process for siting and construction of transmission projects over federal land that are used to support renewable energy generation. ${ }^{147}$ The federal lands that are the subject of this memorandum do not include those situated within the National Interest Electric Corridors discussed in the first part of this section. ${ }^{148}$

Under the terms of the Memorandum, the Department of Energy will designate a single point of contact, a "Lead Agency," for a project that falls under the purview of the agreement. That designation will be roughly based on which agency carries the most significant land management interests related to the project, or is recommended by other impacted agencies. ${ }^{149}$ The Lead Agency then has the responsibility of coordinating action among the various agencies and

\footnotetext{
146 See Memorandum of Understanding Among the U.S. Dept. of Agriculture, Dept. of Commerce, Dept. of Defense, Dept. of Energy, Envtl Protection Agency, The Council on Envtl Quality, the Fed. Energy Reg. Commission, the Advisory Council on Historic Preservation, and the Dept. of the Interior, Regarding Coordination in Federal Agency Review of Electric Transmission Facilities on Federal Land (Oct. 23, 2009), available at http://www.achp.gov/docs/TransmissionMOU.pdf.

147 Id. at $1-2$.

148 Id. at 3.

149 Id.
} 
establishing and efficient permitting schedule. ${ }^{150}$ Importantly, the Lead Agency will maintain a consolidated administrative record regarding the permitting decision and will prepare a unified environmental review document under the National Environmental Policy Act. ${ }^{151}$

The effect of this Memorandum is likely to be of strongest import in Western states that feature large amounts of public land. It might also carry broader significance by providing a window into what a transmission siting process looks like that is divorced from contentious issues of federalism, like those covered in the other subparts of this section. In that respect, the siting process under the Memorandum may present an operating blueprint for what a more federalized, FERC controlled siting process might look like, and a harbinger of things to come if FERC wins its legislative or judicial siting battles.

III. Introduction to the Smart Grid

Because this paper is meant as an introduction to the area of transmission, many issues relevant to a fuller understanding of the grid—such as cost allocation and cost recovery-have been excised for the sake of brevity. There is one general topic that requires at least brief treatment. Thus, this final section provides a basic introduction to the Smart Grid, which in some respects represents an alternate technological path from large-scale transmission development.

\section{The Smart Grid - Developments in the Electricity Distribution Network}

The Smart Grid broadly refers to a basket of technological advancements that are being developed for the distribution level of the grid, i.e., the numerous low-voltage power lines and facilities that carry electricity from substations to individual houses. Up until this point, by contrast, this paper has focused on the transmission level of the grid, where high-voltage lines carry electricity from far-away power plants to nearby substations. Both levels of the grid are undergoing frenetic change. At the distribution level, utilities and software companies want distribution facilities to do more than carry electricity to the end consumer and record its consumption. They are investing heavily to that end-Pike Research, a consultancy firm for the field of clean tech, estimates that over $\$ 200$ billion will be invested worldwide in Smart Grid technologies by 2015 . $^{152}$ The federal government is, again, seeking to capitalize on this investment and, to that end, the Commerce Department's National Institute of Standards and Technology recently finalized its first set of

150 Id. at 5.

151 Id. at 6

152 Pike Research, Smart Grid Investment to Total \$200 Billion Worldwide by 2015, PIKE RESEARCH, http://www.pikeresearch.com/newsroom/smart-grid-investment-to-total-200-billion-worldwide-by-2015. 
technical standards for the smart grid, which, if adopted by FERC, could greatly accelerate the pace of adoption. ${ }^{153}$

The enabler underlying many Smart Grid technologies is the advanced metering infrastructure program which is intended to create a network of digital smart meters with enhanced communication abilities. ${ }^{154}$ Like traditional utility meters, smart meters record the amount of electricity consumed in a particular location but also contain enhanced communication abilities, which allow real-time information about consumption to be sent to utility companies and customers. That ability alleviates the need for monthly site visits by utility meter readers and service technicians and, more importantly, allows utilities to implement flexible electricity prices that change with real-time generation costs. ${ }^{155}$ Consumers can also use real-time information to track price changes and adjust their consumption accordingly, thereby reducing peak electricity demand. ${ }^{156}$ Even small reductions in peak demand can significantly reduce the need for costly renewable energy infrastructure projects, such as high-voltage transmission lines. ${ }^{157}$

Advanced meters also provide the information that utilities require to more adeptly balance load demands on the grid, allowing, for example, greater incorporation of two-way power flows. Twoway power allows small generation devices—such as rooftop solar panels, geothermal generators, and small-wind turbines-to feed excess electricity back onto the grid, which directly reduces the owner's utility bill. Although distributed generation at high levels can cause grid stability problems, the real-time information provided by advanced meters-and the more advanced software modeling and control programs it supports—can mitigate those problems to some extent.

Because greater levels of distributed energy generation and higher levels of energy efficiency roughly correspond with fewer power generation plants, the Smart Grid is sometimes viewed as a competitor to the huge transmission infrastructure build-out. The enormity of the energy challenges facing the U.S. may require embracing both approaches, however. And, at any rate, a

\footnotetext{
153 See Press Release - National Institute of Standards and Technology, NIST Issues First Release of Framework for Smart Grid Interoperability (Jan. 10, 2010).

154 National EnERgy Technology Laboratory, NETL MOdern GRID STRATEgy POWERING OUR 21ST-CENTURY ECONOMY, ADVANCED METERING INFRASTRUCTURE at 5, available at http://www.netl.doe.gov/moderngrid/docs/AMI\%20White\%20paper\%20final\%20021108.pdf.

155 Id. at 5-9.

156 See, e.g., Uwe Dulleck and Sylvia Kaufmann, Do customer information programs reduce household electricity demand?-the Irish program, 32 ENERGY POLICY 1025 (2004) (empirical study finding that consumer education programs decreased electricity demand by 7\%).

157 DEPARTMENT OF ENERGY - THE SMART GRID: AN INTRODUCTION, HOW A SMARTER GRID WORKS AS AN ENABLING ENGINE FOR OUR ECONOMY, OUR ENVIRONMENT, AND OUR FUTURE at 13, available at http://www.oe.energy.gov/DocumentsandMedia/DOE_SG_Book_Single_Pages.pdf.
} 
dual-policy approach is currently reflected in administrative action as witnessed by the roughly $\$ 4$ billion in grants announced for Smart Grid projects in the last few months of 2009. ${ }^{158}$

158 See Press Release, Department of Energy, President Obama Announces \$3.4 Billion Investment to Spur Transition to Smart Energy Grid (October 27, 2009); Press Release, Department of Energy, Secretary Chu Announces \$620 Million for Smart Grid Demonstration and Energy Storage Projects (November 24, 2009). 